\title{
Agnieszka Januszek-Sieradzka
}

\author{
ORCID: 0000-0002-3227-3797 \\ John Paul II Catholic University of Lublin
}

\section{Janusz Smołucha}

\section{Introduction}

Like the earlier issue of the Yearbook, this one also consists of two major parts. The first is devoted to the cultural and intellectual climate of the courts of queens in medieval and modern Europe. At the beginning of the 2000s, general opinion uphold by Polish historiography that we know little about the queens and their role in the state, or about their environment, and that the structures of the courts of Polish duchesses and queens remain outside the mainstream of research, was by all means correct. Over the past twenty years, however, the subject of the courts of Polish queens in the Middle Ages and in the modern era has gained a group of scholars who have increasingly went beyond structural and interpersonal studies, and in Polish studies, the current of queenship, which is part of this problem and which has enjoyed a noticeable popularity in Western historiographies, is more and more visible.

Among the issues that make up the broader subject of the queen's court, on top of the cultural and intellectual aspect of the functioning of these complex and diverse communities, occupies an important place. These are equally interesting and insufficiently researched issues related to the patronage of queens, their role as animators of culture and its participants and recipients, their relations with men of letters and science, artists representing various fields of art, connections with 
universities, the presence of intellectuals and scholars at court and in its surroundings, as well as issues related to the religious life of the court and its spiritual "backstage."

The opening article by Tomasz Graff is devoted to the analysis of the influence of the Polish queen Jadwiga of Anjou on the staffing of episcopal sees during her reign (1384-1386) and co-regency with Władysław Jagiełło (1386-1399). The author's research shows that the queen cooperated constantly with her husband, pursuing a church policy in solidarity with him. In the case of most of the most prestigious episcopal chairs in the Kingdom of Poland, it was King Jagiełło who had the dominant influence on the nomination of candidates for the episcopate, using this tool to create his own political base. The study also proves that many of the views rooted in Polish historiography, and often just suppositions, should be verified on the basis of a new, deeper analysis of the seemingly well-known source base.

Similar observations apply to Maria Piątkowska's article, in which the author, taking Jan Długosz as her guide and informant, examined the journeys undertaken by Queen Jadwiga of Anjou. The role of these "Długosz royal itineraries" was pointed out many years ago by Antoni Gąsiorowski, who aptly noted that among the vast amount of information provided by Długosz's Annals, a prominent place is occupied by information on the routes and dates of royal journeys of the first three Jagiellons. By its very nature, the travels of queen consorts do not find comparable illumination in the work of Jan Długosz, but the analysis of what the chronicler noticed and noted concerning the queen's mobility, and how he explained it, is no less interesting.

Tomasz Rombek, the author of another presented article, paid attention to the issue of the clergy's presence at the courts of Elizabeth of Austria and Elizabeth Jagiellon, wife and the youngest daughter of King Casimir IV Jagiellon. The author determined the personalities of people belonging to the clergy who appear in sources referring to the surroundings of both women as performing various functions there, most often of a pastoral or clerical nature, and, less frequently, working as medics or ministers. The clergy at the courts of both Elizabeths were predominantly men for whom the pinnacle of their careers was the attainment of lower benefices, and only a few managed to reach more significant offices, while two other went on to become bishops.

Agnieszka Januszek-Sieradzka, the author of another article about royal secretaries and people who performed secretarial functions during nearly two centuries of the reign of the Jagiellonian dynasty. She looked at the group of people associated with the courts of the queens, but 
from a different angle. Particular attention was paid to the relationships between these men and the queens, on top of the role they played in the courtly activities of the women monarchs. Because of the secretaries' personal connections to the queens and their special access to the monarchs' wives and their affairs, a look at this group is intriguing from more than just a chancery or even diplomatic standpoint. Recognizing this group can be especially important for knowing and understanding the queens themselves, their relationships with immediate circles along with the people who had constant and close contacts with the queens. Such contacts were often difficult, complicated, and marked by a whole range of relationships and emotions.

An even longer time horizon, more than four hundred years, defines the chronological framework of the findings contained in the article by Jacek Szpak, who examined the relationships between Polish queens, from Jadwiga of Anjou, the wife of Władysław Jagiełło, to Maria Josepha of Austria, the wife of Augustus III of Poland, and the Pauline Shrine of Our Lady at Jasna Góra. Marie Louise Gonzaga, the wife of Władysław IV Vasa and John II Casimir Vasa, Maria Kazimiera, the wife of John III Sobieski, Eleonore of Austria, the wife of Michał Korybut Wiśniowiecki, and Maria Josepha of Austria, the wife of Augustus III of Poland had the most frequent contacts with Jasna Góra. They came repeatedly to the Shrine, prayed before the image of the Virgin Mary, and offered valuable votive offerings.

The next two articles deal with the activities at the courts of queens and the relationships of individuals to them, which are extremely interesting. Aleksandra Barwicka-Makula shows the activity of Stanisław Fogelweder in the service of Queen Anne of Habsburg (1592-1598), the first wife of Sigismund III Vasa. The author reconstructed his position at the courts of Sigismund III and Anne on the basis of his correspondence - especially his letters to Maria Anna of Bavaria and Jan Zamoyski. It follows from the observations made, that lasting uninterruptedly for four decades, Fogelweder's court service was based on loyalty and total devotion to the ruling dynasty.

The relationship between the article's protagonist Damien Mallet and his queen was quite different. Pierre des Noyers was secretary to Queen Marie Louise Gonzaga and later also to Marie Casimire d'Arquien. He was awarded a Polish indigene. He was certainly an extraordinary figure at the Polish court, with many interests and extraordinary writing talents. $\mathrm{He}$ left behind a huge collection of correspondence that he kept with various personalities from all over Europe. Des Noyers was interested in medicine, meteorology, astronomy and astrology. He made meteorological 
observations, conducted medical experiments on his own body and tried to develop his own scientific method with its application in astrology or in perfecting a method of measuring time. Damien Mallet cited a very interesting example related to the determination of the exact time of birth of Queen Maria Anna Vasa.

The part of the Yearbook devoted to the courts of queens closes with an article by Aleksandra Skrzypietz, with whose characters we move to the lively Roman court of Maria Kazimiera Sobieska, who, after the death of her husband, left Poland and settled in the Eternal City with her beloved granddaughter and son, Alexander. From the letters, which the author made the basis of her considerations and which contain an individual, very personal point of view of Maria Kazimiera, emerges first of all the story of the Sobieski family and its individual members, about their relationships and the life of the widow of John III, her feelings and ambitions, shown through the lens of her private theatre. In her correspondence, the Queen never touched on the topic of the plays themselves, gave their titles, or wrote anything about the subjects they addressed. The correspondence, however, shows the pride that Maria Kazimiera felt at the thought of the artistic achievements of her son and granddaughter. The letters are a testimony to the queen's feelings, not a report of the life of her Roman court theatre.

The second part of the Yearbook opens with Barbara Hryszko's text presenting the circumstances of the appointment of the French painter Noël Coypel (1628-1707) as Rector of the French Academy in Rome. The itinerary of his journey from Paris to Rome, which Noëla Coypel made in late 1672/1673 with several young artists accompanying him, is examined in detail. A case study of this journey gave the author a basis for examining the modern travel habits of visiting cities, the churches and palaces within them, and admiring rare art collections.

Marek Hałaburda's article deals with the dispute over the right of patronage and gifts for the office of the provost at the parish church of the Assumption of the Blessed Virgin Mary in Oświęcim, which had not been described in the literature. The paper draws on a broad source base that includes materials deposited in three archives and published sources. This text adds significantly to the body of knowledge about the application of patronage law and the imperfections in its implementation. As it turns out, legal disputes and the need to resolve them continued throughout the centuries until the first half of the 20th century.

Feliks Koneczny's remarks on paedocracy, published in the Stowo daily in 1912, became the basis for Marzena Kutt's analysis of various forms of contemporary political activity among young people. The author 
concludes that the activities of young politicians are too often manipulated by their older colleagues. As Koneczny once emphasized, young people are characterized not only by emotionality and susceptibility to influence and, above all, competence deficiencies. Taking a cue from the famous philosopher of history, the author concludes that the only way to combat paedocracy seems to be to limit the participation of the young in politics.

In the next article, Andrzej Wadas described the activities of the Siberian exile and naturalist Michał Jankowski (1840-1912) and the further fate of his family in the Primorsky Krai and Korea. The author traces the activities of the members of three generations of this family who, despite many adversities, achieved much success both economically and culturally.

In the following text, Krzysztof Duda presented the biography of painter Stanisław Daczyński (1856-1941), a student of Jan Matejko. The author managed to reconstruct important fragments of his private and professional life. After finishing his art studies and leaving Krakow, Daczyński worked at a pottery school in Kolomyia in the Pokuttia region. Traces of his activity can also be found in Vienna, Bochnia and Zakopane. Krzysztof Duda also established the dates of his life and place of burial. The text is enriched with Stanisław Daczyński's drawings depicting himself and the places the artist was connected with. In the last article Agata Kilar addresses the problem of evil in the work of Fyodor Dostoyevsky on the basis of an analysis of the behavior of Pyotr Verkhovensky, the hero of the Demons. 
